Педагогічні умови формування етнопедагогічної культури майбутніх учителів музичного мистецтва в процесі фахової діяльності

\title{
УДК 378.011.3 - 051:78]:39:008
}

\section{ПЕДАГОГІЧНІ УМОВИ ФОРМУВАННЯ ЕТНОПЕДАГОГІЧНОЇ КУЛЬТУРИ МАЙБУТНІХ УЧИТЕЛІВ МУЗИЧНОГО МИСТЕЦТВА В ПРОЦЕСІ ФАХОВОЇ ДІЯЛЬНОСТІ}

\author{
Надія Голубицька \\ викладач кафедри теорії та методики музичної освіти, \\ хорового співу і диригування факультету мистецтв \\ імені Анатолія Авдієвського \\ Національного педагогічного університету імені М.П. Драгоманова, \\ м. Київ, Україна \\ nadijkago@gmail.com
}

\begin{abstract}
Анотація. У статті розроблені педагогічні умови формування етнопедагогічної культури майбутніх учителів музичного мистецтва 3 позиції дослідження сучасних тенденцій розвитку вокально-хорового навчання в контексті вивчення практичного досвіду провідних вітчизняних фахівців-хормейстерів. Розроблені педагогічні умови - фундаменталізація етнопедагогічного базису для розбудови навчального середовища в межах процесу вокальнохорового навчання; формування етнопедагогічної культури майбутніх учителів музичного мистецтва засобами етнопедагогічної деонтологізації в процесі активного застосування праксеологічного підходу - становлять основні шляхи ефективного вирішення означеної проблеми. Застосування означених педагогічних умов у процес вокально-хорового навчання студентів включає практичне введення методів і засобів української народної педагогіки, спрямованих на формування гуманних стосунків спілкування відповідно до національних виховних ідеалів.
\end{abstract}

Ключові слюва: педагогічні умови; етнопедагогічна культура; майбутні вчителі музичного мистецтва; деонтологізація; застосування праксеологічного підходу; деонтологізації в процесі активного застосування праксеологічного підходу.

Постановка проблеми в загальному вигляді. Спираючись на аксіоматичний характер твердження щодо прямої взаємозалежності між правильністю визначення педагогічних умов i ефективністю розробленої методики формування етнопедагогічної культури майбутніх учителів музичного мистецтва, зауважимо, що вся проведена попередньо пошуково-аналітична та дослідно-експериментальна робота була направлена на науково-теоретичне обгрунтування й конкретизацію означених педагогічних умов. Процес їхньої кристалізації проходив через узагальнення сутності та специфіки етнопедагогічної культури майбутніх учителів музичного мистецтва, через дослідження сучасних тенденцій розвитку вокально-хорового навчання в контексті вивчення практичного досвіду провідних вітчизняних фахівцівхормейстерів, через системно-структурний аналіз компонентної структури досліджуваного феномена, а також через аналіз результатів пілотного опитування щодо ставлення студентів і викладачів до проблем формування етнопедагогічної культури. 
Педагогічні умови формування етнопедагогічної культури майбутніх учителів музичного мистецтва в процесі фахової діяльності

Аналіз останніх досліджень i публікацій. Теоретичні аспекти етнопедагогічної підготовки майбутніх учителів музичного мистецтва висвітленні в працях А. Болгарського, О. Єременко, В. Орлова, О. Ростовського, О. Рудницької, О. Хижної та ін.; особливості творчого підходу як основи фахової діяльності студентів факультетів мистецтв висвітленні в роботах Д. Богоявленської, А. Козир, Г. Падалки, О. Хоружої, Г. Щедровицького, О. Щолокової та ін. Недостатньо вирішеним залишається науково-теоретичне обгрунтування, розробка й конкретизація педагогічних умов формування етнопедагогічної культури майбутніх учителів музичного мистецтва.

Формулювання цілей статті. Метою статті $є$ розробка педагогічних умов формування етнопедагогічної культури майбутніх учителів музичного мистецтва.

Результати дослідження. Ефективність методичного забезпечення формування етнопедагогічної культури майбутніх учителів музичного мистецтва залежить від встановлення означених педагогічних умов як певних опорних стрижнів, що обумовлюють основні напрямки організації вокально-хорового навчання відповідно до обраної методичної стратегії [3].

Розроблення й конкретизація педагогічних умов формування етнопедагогічної культури майбутніх педагогів-музикантів, керівників шкільних хорових колективів визначаються, з одного боку, специфікою процесу вокальнохорового навчання, а з іншого боку - специфікою процесу навчання української етнопедагогіки. Інтегрування характерних ознак вокально-хорової й етнопедагогічної навчальної діяльності студентів факультетів мистецтв педагогічних університетів обумовлює визначення провідних орієнтирів для розроблення й визначення педагогічних умов ефективного формування етнопедагогічної культури майбутніх учителів музичного мистецтва.

Під час розроблення означених педагогічних умов ми вважаємо за доцільне спиратися на залучення класичного й інноваційного методичного інструментарію 3 вокально-хорового навчання, який постійно оновлюється та вдосконалюється, а також на застосування методів, засобів і прийомів української народної педагогіки, передусім, на український музичний фольклор і національне музичне мистецтво. 3 огляду на вищезазначене науково-теоретичне обгрунтування найбільш сприятливих педагогічних умов ефективного формування етнопедагогічної культури майбутніх учителів музичного мистецтва доцільно не відривати від контексту навчального середовища, яке функціонує в межах процесу вокально-хорового навчання на факультетах мистецтв педагогічних університетів.

Якщо екстраполювати зміст узагальненого навчального середовища, яке, за твердженням Ю. Бикова, складається з природних інтелектуальних складових (учасників навчального процесу) і штучних складових (засобів навчального процесу - носіїв штучного інтелекту) [1, с. 59], на конкретне навчальне середовище, яке створено в межах процесу вокально-хорового навчання 
Педагогічні умови формування етнопедагогічної культури майбутніх учителів музичного мистецтва в процесі фахової діяльності

майбутніх учителів музики, то отримаємо такі складові. До природних інтелектуальних складових належать носії природного інтелекту, що беруть участь у процесі вокально-хорового навчання, зокрема студенти всіх курсів як суб'єкти процесу вокально-хорового навчання, головні отримувачі й споживачі освітніх послуг музично-педагогічного ВНЗ; представники професорськовикладацького складу, що забезпечує викладання навчальних курсів «Хорове диригування», «Хоровий клас», «Хорознавство», «Методика музичного виховання», «Виробнича педагогічна практика з музики», «Постановка голосу», «Виконавський практикум» як суб’єкти навчального процесу, надавачі освітніх послуг музично-педагогічного ЗВО; концертмейстерський склад, що бере участь у групових та індивідуальних заняттях із «Хорового диригування», «Хорового класу», «Постановки голосу» та «Вокалу»; допоміжний лаборантський склад, який забезпечує підготовку та функціонування технічних засобів вокальнохорового навчання.

До штучних складових, засобів-носіїв штучного інтелекту, що беруть участь у процесі вокально-хорового навчання, належать підручники, навчальнометодичні посібники, типові та робочі навчальні програми 3 вищезазначених курсів та інша література навчально-методичного характеру, музичні інструменти, що забезпечують акомпанемент під час хорового, ансамблевого та сольного співу, а також найбільш актуальні сьогодні інформаційнокомунікаційні, медійні засоби вокально-хорового навчання.

Слід зупинитися на провідній ролі інформаційно-комунікаційних, медійних засобів сучасного вокально-хорового навчання. Систематичне залучення означених засобів $\epsilon$ важливим чинником удосконалення навчального середовища, створеного в межах вокально-хорового навчання. Зокрема, систематичне залучення інформаційно-комунікаційних, медійних засобів забезпечує перманентне розширення простору навчального середовища на основі постійного оновлення й необмеженості інформації в галузі вокально-хорового навчання; збільшення доступності навчального матеріалу для всіх учасників цього процесу і скорочення часу на його віднайдення; можливість для аналізу, оцінювання й самооцінювання результатів вокально-хорового навчання, збережених на електронних носіях; можливість індивідуалізованого отримання й споживання навчальної інформації.

Водночас ефективність формування етнопедагогічної культури майбутніх учителів музичного мистецтва залежить від створення такого навчального середовища в межах вокально-хорового навчання, яке б цілеспрямовано сприяло не лише провадженню навчальної вокально-хорової діяльності, але й забезпечило поступове накопичення студентами етнопедагогічних знань, оволодіння системою цінностей української народної педагогіки, а також набуття власного досвіду етнопедагогічної діяльності.

На практиці створення такого навчального середовища вимагає пошуку для педагогічного інструментарію «спільного знаменника», спроможного 
Педагогічні умови формування етнопедагогічної культури майбутніх учителів музичного мистецтва в процесі фахової діяльності

забезпечити гармонізацію й інтегрування вокально-хорової й етнопедагогічної навчальної діяльності в процесі вокально-хорового навчання. У якості такого «спільного знаменника» для розроблення означеного інструментарію виступають провідні засоби української народної педагогіки і опорні засоби української етномузичної педагогіки - український музичний фольклор i українське національне музичне мистецтво.

Науково-теоретичне обгрунтування й окреслення педагогічних умов формування етнопедагогічної культури студентів у процесі вокально-хорового навчання ми провадили, виходячи 3 позицій компетентнісного підходу, який передбачає формування в майбутніх учителів музичного мистецтва предметних компетенцій [2]. У процесі вокально-хорового навчання майбутній фахівець здобуває компетенції хормейстера, керівника шкільного хорового колективу, вокального ансамблю тощо на основі набуття практичного диригентського досвіду, досвіду в галузі організації колективного музикування школярів, роботи 3 хором тощо. Такий досвід студент може отримати виключно під час практичної вокально-хорової діяльності, яка являє собою опрацювання вокально-хорового репертуару.

3 огляду на вищезазначене закладення в основу вокально-хорового репертуару студентів факультетів мистецтв педагогічних університетів зразків українського музичного фольклору й українського національного музичного мистецтва: опорних засобів української етномузичної педагогіки, які, концентруючи в собі систему цінностей українського етносу, у процесі вивчення впливають на формування компонентів духовності відповідно до національних виховних ідеалів, забезпечить гармонізацію й інтегрування вокально-хорової й етнопедагогічної навчальної діяльності в процесі вокально-хорового навчання.

Саме українська народна пісенність в обробках для хору А. Авдієвського, Ф. Колесси, В. Косенка, М. Леонтовича, М. Лисенка, Б. Лятошинського, Л. Ревуцького М. Скорика, К. Стеценка, І. Шамо та ін., а також їхні авторські вокально-хорові шедеври (хори, кантати, ораторії, хорові номери з опер тощо), включені на постійній основі в навчально-педагогічний репертуар студентських хорових колективів, у програми для індивідуальних занять із «Хорового диригування», здатні підвести фундаментальний етнопедагогічний базис під педагогічне спілкування викладачів диригентсько-хорових дисциплін і студентів як основних носіїв природного інтелекту в навчальному середовищі, створеному в межах процесу вокально-хорового навчання. 3 огляду на вищезазначене мова йде про фундаменталізацію опорних засобів української етномузичної педагогіки - українського музичного фольклору й українського національного музичного мистецтва - як етнопедагогічного базису процесу вокально-хорового навчання. У цьому випадку під означеною фундаменталізацією ми розуміємо педагогічне забезпечення студентів факультетів мистецтв педагогічних університетів інтегрованим комплексом знань у галузі вокально-хорового репертуару, який складається із зразків різних родів і жанрів українського музичного фольклору та 
Педагогічні умови формування етнопедагогічної культури майбутніх учителів музичного мистецтва в процесі фахової діяльності

різних жанрів українського класичного й сучасного вокально-хорового мистецтва.

Гармонізації та взаємному інтегруванню вокально-хорової й етнопедагогічної навчальної діяльності також сприятиме активне застосування означених засобів української народної педагогіки - українського музичного фольклору та національного музичного мистецтва - у розробленні штучних складових навчального середовища: засобів-носіїв штучного інтелекту, що беруть участь у процесі вокально-хорового навчання.

Укладання на основі української народної пісенності й найкращих зразків українського класичного і сучасного вокально-хорового мистецтва хрестоматій навчально-педагогічного репертуару для «Хорового класу», підручників i навчально-методичних посібників із «Хорознавства», «Хорового диригування» тощо вможливить створення етнопедагогічного базису для повноцінної розбудови навчального середовища, спрямованого на етнопедагогізацію вокально-хорового навчання.

Слід зупинитися на необхідності розроблення етнопедагогічних напрямків для відповідного спрямування таких важливих штучних складових навчального середовища - носіїв штучного інтелекту - як інформаційно-комунікаційні, медійні засоби сучасного вокально-хорового навчання. Сполучаючи в процесі розбудови навчального середовища інформаційно-комунікаційні, медійні засоби вокально-хорового навчання й опорні засоби української етномузичної педагогіки, український музичний фольклор і національне музичне мистецтво під час мультимедійного аранжування українських народних пісень, демонстрації на заняттях за допомогою електронних носіїв найбільш яскравих інтерпретацій творів українських композиторів національними хоровими колективами, викладач забезпечує перманентне розширення простору навчального середовища на основі необмеженості доступу до прослуховування зразків українського музичного фольклору та національного музичного мистецтва; збільшення доступності навчального матеріалу 3 проблем вокально-хорового навчання, музичної фольклористики тощо для всіх учасників навчального середовища $\mathrm{i}$ скорочення часу на його віднайдення; можливість для аналізу, оцінювання й самооцінювання результатів виконання вокально-хорового репертуару, збережених на електронних носіях; можливість індивідуалізованого розширення інтонаційно-художнього фонду зразків українського музичного фольклору та національного музичного мистецтва.

3 огляду на вищезазначене доцільно визначити в якості однієї 3 педагогічних умов формування етнопедагогічної культури майбутніх учителів музичного мистецтва фундаменталізацію етнопедагогічного базису для розбудови навчального середовища в межах прочесу вокально-хорового навчання, яке забезпечує гармонізацію й інтегрування вокально-хорової й етнопедагогічної навчальної діяльності шляхом системного застосування опорних засобів української етномузичної педагогіки - українського музичного фольклору та 
Педагогічні умови формування етнопедагогічної культури майбутніх учителів музичного мистецтва в процесі фахової діяльності

національного музичного мистецтва - у розробленні педагогічного інструментарію для вивчення диригентсько-хорових дисциплін (навчального вокально-хорового репертуару, хрестоматій навчально-педагогічного репертуару для «Хорового класу», підручників i навчально-методичних посібників із «Хорознавства», «Хорового диригування» тощо).

Системне застосування опорних засобів української етномузичної педагогіки: українського музичного фольклору та національного музичного мистецтва, які виконують функцію цінностей-засобів у загальній системі цінностей української народної педагогіки, під час розбудови навчального середовища забезпечує етнопедагогічну спрямованість процесу вокальнохорового навчання та сприяє цілісному формуванню етнопедагогічної культури майбутнього вчителя музичного мистецтва.

Ефективне формування етнопедагогічної культури майбутніх учителів музичного мистецтва, що базується на системі цінностей української педагогіки, передбачає актуалізацію в навчальному середовищі цінностей-відносин під час педагогічного спілкування. Педагогічне спілкування, яке спирається на цінностівідносини української народної педагогіки, має відповідати основним позиціям української етнопедагогічної деонтології: взаємній повазі й розумінню учасників навчально-виховного процесу, особливій повазі до старших, доброзичливості, милосердю, співчуттю тощо. Отже, другою педагогічною умовою $є$ формування етнопедагогічної культури майбутніх учителів музичного мистецтвва засобами етнопедагогічної деонтологізації в процесі активного застосування праксеологічного підходу.

Застосування праксеологічного підходу обумовлює необхідність не просто дотримання в навчальному середовищі вищезазначених позицій спілкування між його суб'єктами, а поступового накопичення комунікативно-деонтологічного досвіду гуманних взаємовідносин у процесі вокально-хорового навчання. Набуття й накопичення такого комунікативно-деонтологічного досвіду дозволило б студентам спілкуватися на основі гуманних відносин не тільки в межах навчального середовища, але й перенести гуманні відносини в повсякденне спілкування.

Отже, перенесення накопиченого студентом у навчальному середовищі комунікативно-деонтологічного досвіду на побутовий рівень обумовило б модель поведінки, яка побудована на базі цінностей-відносин української народної педагогіки й відповідає іiі виховним ідеалам. Сформованість означеної моделі поведінки засвідчує сформованість етнопедагогічної культури майбутнього вчителя музичного мистецтва в частині цінностей-відносин.

Для накопичення такого комунікативно-деонтологічного досвіду гуманних взаємовідносин нами розроблено сукупність навчально-методичних заходів, спрямованих на формування в процесі вокально-хорового навчання комфортного клімату гуманних взаємовідносин між учасниками навчального процесу. Розроблення й упровадження означених заходів мало на меті створення 
Педагогічні умови формування етнопедагогічної культури майбутніх учителів музичного мистецтва в процесі фахової діяльності

сприятливих умов для формування етнопедагогічної культури майбутнього вчителя музичного мистецтва в частині цінностей-відносин.

Висновки 3 дослідження і перспективи подальших розвідок у цьому напрямі. Сукупність означених навчально-методичних заходів включає практичне введення методів i засобів української народної педагогіки, спрямованих на формування гуманних відносин спілкування відповідно до національних виховних ідеалів, у процес вокально-хорового навчання, що включає цілеспрямоване роз'яснення сутності, змісту, особливостей застосування та педагогічного значення для музичного навчання на уроках музичного мистецтва практично-дієвих, сугестійних, переконувальних тощо груп методів української народної педагогіки (навчальний курс «Методика музичного виховання»); систематичне застосування й відпрацювання означених методів на уроках музичного мистецтва в загальноосвітній школі (навчальний курс «Виробнича педагогічна практика з музики»); цілеспрямоване й систематичне роз'яснення педагогічного потенціалу українського музичного фольклору та національного музичного мистецтва для розбудови гуманних взаємовідносин у процесі вокально-хорового навчання, що сприяє формуванню музично-творчих здібностей, вокально-хорових умінь і навичок, а також музичної культури як сегмента духовної культури особистості (навчальні курси «Хорове диригування», «Хоровий клас», «Хорознавство», «Методика музичного виховання», «Виробнича педагогічна практика 3 музики», «Постановка голосу», «Вокал», «Виконавський практикум»); уведення елементів української педагогічної деонтології до навчальних курсів, що забезпечують процес перебігу вокальнохорового навчання (навчальні курси «Хорове диригування», «Хоровий клас», «Методика музичного виховання», «Виробнича педагогічна практика з музики», «Постановка голосу», «Вокал»).

\section{СПИСОК ВИКОРИСТАНИХ ДЖЕРЕЛ}

1. Биков, В. Ю. (2004). Навчальне середовище сучасних педагогічних систем. Професійна освіта: педагогіка і психологія. Україно-польський журнал, 4, 59-79.

2. Бондаренко, О. О. і Бондаренко О. С. (2013). Компетентнісний підхід як засіб управління якістю освіти. Матеріали Всеукр. наук.-практ. конф. «Науково-методичні підходи до викладання управлінських дисциплін в контексті вимог ринку праці». (С. 72-79). Дніпропетровськ: Біла К.О.

3. Гончаренко, С. У. (2011). Український педагогічний енциклопедичний словник. Рівне, Україна: Волинські обереги.

\section{ПЕДАГОГИЧЕСКИЕ УСЛОВИЯ ФОРМИРОВАНИЯ ЕТНОПЕДАГОГИЧЕСКОЙ КУЛЬТУРЫ БУДУЩИХ УЧИТЕЛЕЙ МУЗЫКАЛЬНОГО ИСКУССТВА В ПРОЦЕССЕ ПРОФЕССИОНАЛЬНОЙ ДЕЯТЕЛЬНОСТИ}

\section{Надежда Голубицкая}

преподаватель кафедры теории и методики музыкального образования, 


\title{
Н. ГОЛУБИЦЬКА
}

Педагогічні умови формування етнопедагогічної культури майбутніх учителів музичного мистецтва в процесі фахової діяльності

\section{хорового пения и дирижирования факультета искусств} имени Анатолия Авдеевского

Национального педагогического университета имени М.П. Драгоманова,

г. Киев, Украина

nadijkago@gmail.com

Аннотация. В статье разработаны педагогические условия формирования етнопедагогической культуры будущих учителей музыкального искусства с позиции исследования современных тенденций развития вокально-хорового обучения в контексте изучения практического опыта ведущих отечественных специалистов-хормейстеров. Разработанные педагогические условия - фундаментализация етнопедагогического базиса для развития учебной среды в рамках процесса вокально-хорового обучения; формирование етнопедагогической культуры будущих учителей музыкального искусства средствами етнопедагогической деонтологизации в процессе активного применения праксеологического подхода - составляют основные пути эффективного решения этой проблемы. Применение указанных педагогических условий в процесс вокально-хорового обучения студентов включает практическое введение методов и средств украинской народной педагогики, направленных на формирование гуманных отношений общения в соответствии с национальными воспитательными идеалами.

Ключевые слова: педагогические условия; етнопедагогическая культура; будущие учителя музыкального искусства; деонтологизация; применение праксеологического подхода; деонтологизация в процессе активного применения праксеологического подхода.

\section{PEDAGOGICAL CONDITIONS FOR FORMING ETHNOPEDAGOGICAL CULTURE OF FUTURE MUSIC ART TEACHERS IN THE PROCESS OF PROFESSIONAL ACTIVITY}

\author{
Nadiia Holubytska \\ Teacher of the Department of Theory and Methodology of Music Education, \\ Choral Singing and Conducting of the Faculty of Arts \\ named after Anatolii Avdiievskyi \\ National Pedagogical Dragomanov University \\ Kyiv, Ukraine \\ nadijkago@gmail.com
}

\begin{abstract}
The article deals with the pedagogical conditions for forming ethno-pedagogical culture of future musical art teachers from the standpoint of studying modern tendencies in the development of vocal-choral learning in the context of studying the practical experience of leading domestic experts-choirmaster. Theoretical aspects of the ethnopedagogical training of future musical art teachers are covered in the works by A. Bulharskyi, O. Yeremenko, V. Orlov, O. Rostovskyi, O. Rudnytskyi, and O. Khyzhna.

The purpose of the article is to develop the pedagogical conditions for forming the ethnopedagogical culture of future musical art teachers. Pedagogical conditions are developed: fundamentalization of the ethnopedagogical basis for the development of the learning environment within the process of vocal and choral training; the formation of the ethnopedagogical culture of future musical art teachers by means of ethnopedagogical deontologization in the process of the active use of the praxeological approach - constitute the main ways of effective solution of this problem.
\end{abstract}




\section{Н. ГОЛУБИЦЬКА}

Педагогічні умови формування етнопедагогічної культури майбутніх учителів музичного мистецтва в процесі фахової діяльності

In conclusion, the author notes that the set of the indicated educational and methodological measures includes the practical introduction of methods and means of Ukrainian folk pedagogy, aimed at forming humane communication relationships in accordance with national educational ideals, in the process of vocal and choral learning, which includes a purposeful explanation of the essence, content, peculiarities of use and pedagogical value for musical training at the lessons of musical art of practical, active, persuasive, etc. groups of methods of Ukrainian folk pedagogy; systematic application and development of the indicated methods at the music art lessons at secondary school; purposeful and systematic explanation of the pedagogical potential of Ukrainian folk music and national musical art for the development of humane relationships in the process of vocal and choral training, which contributes to the formation of musical and creative abilities, vocal and choral skills and musical culture as a segment of the spiritual culture of the individual; introduction of elements of Ukrainian pedagogical deontology to the training courses that ensure the process of vocal and choral training.

Key words: pedagogical conditions; ethnopedagogical culture; future musical art teachers; deontologization; application of the praxeological approach; deontologization in the process of active use of the praxeological approach.

\section{REFERENCES (TRANSLATED AND TRANSLITERATED)}

1. Bykov, V. Yu. (2004). Educational environment of modern pedagogical systems. Profesiina osvita: pedahohika i psykholohiia. Ukraino-polskyii zhurnal, 4, 59-79.

2. Bondarenko, O. O., \& Bondarenko, O. S. (2013). Competency approach as a means of quality education management. Proceedings from Vseukrainska naukovo-praktychna konferentsiiia "Naukovo-metodychni pidkhody do vykladannia upravlinskykh dystsyplin v konteksti vymoh rynku pratsi”. (Pp. 72-79). Dnipopetrovsk: Bila K.O.

3. Honcharenko, S. U. (2011). Ukrainian Pedagogical Encyclopedic Dictionary. Rivne, Ukraine: Volynski oberehy.

Матеріали надійшли до редакції 01.12.2018 р. 